Chapter IV

\title{
THE LAST THINGS
}


The last period of Soloviev's life was one of both remarkable intensity and remarkable variety. Many of the themes that the philosopher had developed in his early and middle periods are approached with a renewed vigour and focus; previously diverging directions in thought are integrated, and new ones discovered in their interaction. In The Life Drama of Plato (1898) and his work on the Platonic dialogues, Soloviev brings to consummate expression his relation to one of the two great influences in his philosophical development; and, in Theoretical Philosophy (1897-99), he articulates the fruit of lifelong reflection on the other - Hegel. All of this receives peculiar illumination, not the shadow of eclipse, in the context of the pathos of the end in which Three Conversations and Short Story of the Antichrist (1900) are written. Far from breaking with his previous output, the works of the period from 1897 to his death in 1900 represent an intensification of the foundational impulse with which his philosophy began - the intuition of the unity of the spiritual and material realms - as well as a strengthening of the desire to externalize that intuition in immortal form.

Soloviev's brand of religious philosophy had always exhibited a strongly eschatological thrust: the first principles of being and creation had place only insofar as they lead to knowledge of how to act in relation to what is; when what is proved to be involved in a dynamic process of becoming, such action became the correlation of the individual with the being that would become incarnate at 'the end.' In this last period, however, the philosopher's embracing of the pathos of the end results in a subtle shift in his understanding both of the linearity of the historical process and of the correlation between the individual and universal components of the task of the spiritualization 
of matter. ${ }^{1}$ The core of this change rests in his eschatology, and is best explored through an investigation of two phenomena which in one way or another exerted a definitive influence on the course of Soloviev's life and work: love and beauty.

\section{LOVE}

There can be little doubt that Soloviev's thought on love is the most controversial aspect of his legacy. In the early, unpublished La Sophia, in mediumistic script, we find a statement which, though more explicit than anything in the published work, finds echoes right up to his mature period. 'God loves everything, nature,' he wrote, 'with a direct and real love, as a man loves a woman with whom he is in love, since the relationship is the same: nature is the other half of God himself. Thus, the universal love of God is identical to natural or sexual love.'2 On the basis of this and many analogous proclamations, Sergii Bulgakov, though mitigating his charge by claiming that it sits poorly with Soloviev's theology as a whole, talked of the philosopher's 'sexualization of the Eternal Feminine' and the 'fateful incursion of carnal sensuality into the spiritual realm.' ${ }^{3}$

While Soloviev clearly perceived and did his best to remain faithful to the 'subtle but precise line separating corporeal beauty from carnal' in his ideal of 'spiritual corporeality,' ${ }^{4}$ it seemed to most that this line

1 If this development can be understood as a transition from what biblical scholars call 'prophetic eschatology,' the optimistic view according to which God will restore the Earth through historical processes, to 'apocalyptic eschatology,' the pessimistic perspective whereby the future 'breaks in on' the present, it is only with significant reservations. The principal characteristics of apocalyptic, which David Aune defines as the 'temporal dualism of the two ages' and the 'radical discontinuity between this age and the next, coupled with pessimism regarding the existing order and otherworldly hope directed toward the future order,' can only be attributed to Soloviev based on a grave misunderstanding of his later work. See D. Aune, 'Apocalyptic,' in Westminster Dictionary of New Testament and Early Christian Literature, Louisville KY, and London, 2003, pp. $46-50$ (p. 48).

2 PSS, II, p. 69.

3 S.N.Bulgakov, 'Muzhskoe i zhenskoe v Bozhestve,' in S.N.Bulgakov, Religioznyifilosofskii put', ed. A. P. Kozyrev, Moscow, 2003, pp. 343-65 (p. 357).

$4 \quad$ FI, p. 84. 
was so elusive as to be practically indiscernible. The philosopher, who believed himself to have outdone Plato in safeguarding the crown of the celestial Aphrodite Uranios from the vulgar Aphrodite Pandemus, ${ }^{5}$ and who reproached Pushkin for allowing his 'genius of pure beauty' to become the Whore of Babylon, ${ }^{6}$ could not protect himself or his legacy from similar accusations in his direction. We are not so much concerned, however, with how far his divine Sophia avoids the tarnish of carnal sensuality, as with the problem that arises from his resolution of the role of humanity in the eschatological task of the spiritualization of matter, the final union of the heavenly and the earthly. This problem, to state it in its simplest terms, consists in the fact that both the disunity of spirit and matter that characterizes the fallen world and humanity and their ultimate reunification and restoration in the Kingdom of God are conditional on a kind of sensual desire, each differing according to its goal. Desire is the reason for the split, desire the ground for their reunification. Describing the results of the Fall, Soloviev writes:

The kingdom of death is established; heaven and earth are separated by the human's desire immediately and materially to possess earthly reality, finite existence; humanity desired to experience and savour everything in external feeling. It desired to unite its heavenly spirit with the dust of the earth in an external and superficial bond. But such a bond cannot last, and necessarily leads to death. ${ }^{7}$

Soloviev's argument here is in no way unique to him. It resonates with many Gnostic sources, as well as the work of various Christian mystics, which posited primordial desire on the part of the World Soul as the cause of the Fall. But it is in the means the philosopher promotes as effecting the eradication of death, which consists in a kind of non-

$5 \quad S^{1}$, II, p. 534; PSS, II, pp. 209-10, 369. The myth of the two Aphrodites, one base and one exalted, is found in Pausanius' speech in Plato's Symposium. See Plato, Symposium, ed. C. Gill, London, 1999, pp. 12-13.

6 FI, pp. 277-78. Soloviev makes much of the fact that, in an 1826 letter to Aleksei Vul'f, Pushkin described Anna Kern, once the inspiration for his most elevated poetry, as the 'Whore of Babylon.' A. S. Pushkin, Pis'ma, ed. B. L. Modzalevskii, 3 vols, Moscow, 1989, II, p. 10.

$7 \quad$ SS, XI, p. 347. 
continuous analogue of the very erotic desire that led to the Fall, that his approach diverges from both. In his middle period, the erotic thematic is largely concealed so that, while love had been consistently presented as the eschatological means of the reunification of spirit and matter from early on, its precise determinations were not immediately evident in Soloviev's published work until much later. In the following passage from La Russie et l'église universelle, for example, Soloviev gives his reader a reasonable idea of his eschatological goal but speaks in very general terms about the nature of the love by which it is achieved:

To gain victory over death, humanity should join itself with all, not superficially in its sensuality, but in the absolute centre which is God. The universal human is reunited by Divine love, which not only elevates humanity to God but, identifying itself interiorly with God, gives it the possibility to embrace in Her all that is, i.e. uniting itself with the whole creation in an indissoluble and eternal bond. This love brings down the grace of God onto earthly nature and celebrates victory not only over moral evil, but over its physical consquences - illness and death - as well. The work of this love is the final Resurrection [...] The circle of universal life closes with the resurrection of flesh, the reunification of humanity in its wholeness, the final incarnation of Divine Wisdom. ${ }^{8}$

Much of what Soloviev writes here will be familiar based on our previous exposition. We have followed how the philosopher conceived the prophetic displacement of the centre of human being to God through feeling, a movement that we further traced through reverence to amor ascendens, a desire for God as the absolute source of all being. In this section, it is the nature of this final, descending love - the bringing down of the grace of God onto all creation - that concerns us; that is, love as the eschatological principle whose 'work' Soloviev posits as the 'final Resurrection.'

Christian thought has traditionally conceived of the movement of love as founded on a duality, the ascending love of humanity to God and the descending love of God to humanity, which encounter each other most completely in the Incarnation, which is thus their realized union. ${ }^{9}$

Ibid., pp. 347-38.

See P. Evdokimov, The Sacrament of Love: The Nuptial Mystery in the Light of the Orthodox Tradition, Crestwood NY, 1985, p. 79. 
Amor ascendens, which rises from lower to higher as a kind of reverential desire, was associated with eros - a worldly, creaturely love which seeks its own fulfilment - and amor descendens, the gracious love of the Creator God that gives without thought of gain, with agape. ${ }^{10}$ As a consequence, while the initial ascent of the individual believer into the realm of divinity may have been predicated on the winged flight of Eros, upon reaching its destination erotic love was of necessity purified of all that was fleeting, particular, self-deriving, and drawn into the self-giving, sacrificial movement of agapeic love. The Christian scriptural canon itself has no place whatsoever for the Hellenistic concept of eros, which occurs nowhere in the Greek New Testament or the Septuagint translation of the Hebrew Bible, nor does it feature in any substantial way in the writings of the early Church Fathers. ${ }^{11}$ Twentieth-century theology, particularly in the reformed tradition, has largely cemented the antithesis between eros and agape, resulting in the almost wholesale rejection of the former. ${ }^{12}$

10 The other word for love encountered in the Bible and early Christian literature is philia, which is often compared to brotherly love, or friendship. It is interesting to note that the triumvirate of the great theological minds of late-nineteenth and earlytwentieth-century Russian culture - Soloviev, Bulgakov, and Pavel Florenskii - were evenly split over which kind of love to regard as the most essential. If Soloviev gravitated toward eros and Bulgakov toward agape, Florenskii found the closest representation of his ideal in philia, which he saw as corresponding most exactly to the meaning of the Russian liubit'. See P. Florenskii, The Pillar and Ground of the Truth, Princeton, 1997, pp. 286-89.

11 'Even in the apostolic fathers we find only a single occurrence of eros (Ignatius, ad Rom. 7.2), and here it is used only to denote the love which the author declares that he has left behind him as crucified.' K. Barth, 'Agape and Eros,' in Church Dogmatics: A Selection, Louisville \& London, 1994, pp. 173-93 (p. 177). In Beyond Good and Evil, Nietzsche saw the contemporary association of the erotic with sin as having its source in Christian tradition: 'Christianity gave Eros poison to drink; he did not die of it, certainly, but degenerated into vice.' F. Nietzsche, Beyond Good and Evil, New York, 1989, p. 131. Bulgakov, however, mentions Symeon the New Theologian and Gregory Palamas as later fathers who incorporated a positive interpretation of eros into their writings. See S. N. Bulgakov, The Comforter, Grand Rapids MI, 2004.

12 See, especially, A. Nygren, Agape and Eros, London, 1953. Karl Barth, though diverging from Nygren's antithetical juxtaposition of agape and eros, is just as categorical in his condemnation of eros, and its incompatibility with agape: 'Erotic love is a denial of humanity [...] Agape cannot change into eros, or eros into agape.' Barth, 'Agape and Eros,' p. 189. 
Yet, as Soloviev demonstrates in his article on love for the BrockhausEfron Encyclopaedia, although the biblical lexicon avoids the term eros, there is a strong tradition of erotic symbolism in the biblical literature. ${ }^{13}$ From the comparison of Israel's relation to God in the Hebrew Bible to that of lovers in the writings of prophets such as Hosea, the relation of the Church to Christ in the New Testament to that of bride to bridegroom in the book of Revelation, or the yet more overtly erotic language of the Song of Songs, the examples are many and wide-ranging. Christian mysticism, too, is abundant in erotic imagery, and one does not have to look far to find narrations of the mystic's erotic experience of God. Origen is one of the earliest such examples, and it is telling that Soloviev both in his lifetime and posthumously was compared with the early church father. ${ }^{14}$ Yet, as Grace Jantzen points out, in Origen, as in the great majority of Christian mystics, 'the use of erotic imagery was at the expense of the valuation of real sexual relations. It used the language of passion, but forbade any actual physical passion in an effort to channel all desire away from the body and towards God.'15 Even in contemporary attempts to recover the erotic and integrate human sexuality within a holistic vision of life based on a Christology open to the possibility of real passion, there remains an emphasis on the overcoming, or instrumentalization, of eros for purposes at least potentially incidental to its own vocation. Such an approach can be seen, for example, in Pope Benedict XVI's 2005 encyclical Deus caritas est, whose goal in large part was to reaffirm the rights of eros in Christian life. While he writes that the 'universal principle of creation - the Logos, primordial reason - is at the same time a lover with all the passion of a true love' wherein eros is 'supremely ennobled,' it is so precisely because 'at the same time it is so purified as to become one

$13 \quad$ SS, x, pp. 236-37.

14 Soloviev responded to real or imagined claims that he had, like Origen, castrated himself, in an obscene poem sent to Sergei Trubetskoi. 'K istorii odnoi druzhby,' pp. 20-21. In one of the earliest works on the philosopher (1st ed. 1902), Aleksandr Nikol'skii dubbed Soloviev the 'Russian Origen.' A. Nikol'skii, Russkii Origen XIX veka Vl. S. Solov'ev, St Petersburg, 2000.

15 G. Jantzen, Power, Gender and Christian Mysticism, Cambridge, 1995, p. 91. 
with agape. ${ }^{16}$ Bulgakov himself, while positively reworking Soloviev's conception of eros as spiritual 'syzygy', is extremely careful not to ignore the rights of agape. 'In the dual character of churchly love as agape and as eros,' he wrote in The Comforter, 'there is manifested the antinomic duality of the Christian path as ascesis and creative activity, of repentant humility and creative inspiration. Self-renunciation is realized in agape: an individual dies in his egoism in order to live in and by the whole. In eros, an individual, experiencing inspiration to the point of self-transcendence, ascends to creative self-revelation. ${ }^{17}$ It was this path of Eastern ascesis that Nikolai Berdiaev believed Soloviev to have strayed from, seeing in the philosopher a model of Western mysticism, which he interprets negatively:
Catholic mysticism is sensual [...] The imitation of the Lord's passion, the state of being in love with Christ - all this is possible only when Christ is an object outside and over the human being, an object of striving and not inwardly received [...] In the West, in Catholicism, there has always been not so much a marriage of humanity and God as the human being in love. And the great mission of the Catholic West has perhaps been to disclose the mystical truth about the state of being in love as a creative force. ${ }^{18}$

The most serious aspect of Berdiaev's accusation is not its numbering of Soloviev amongst the Catholic West - debate over the 'Orthodoxy' of the philosopher's thought is still very much a subject of debate-

16 Benedict XVI, 'Deus Caritas est,' 25 December 2005, <http://www.vatican.va/holy_ father/benedict_xvi/encyclicals/documents/hf_ben-xvi_enc_20051225_deus-caritasest_en.html> [accessed 18 July 2008]

17 Bulgakov, The Comforter, p. 322. Bulgakov's definition of prophecy earlier in the same work as the 'eros of the spirit' comes very close to Soloviev's own understanding of prophetic activity. But there are subtle differences. For Bulgakov, prophecy is an 'extremely active state of the spirit, in which the latter strives to meet the higher principle' and, for this reason, an 'extremely creative state of the human spirit' (p. 292). To turn into true divine-human activity, therefore, prophecy needs to accept the passivity given outside itself in the self-renunciation to God's agapeic love. Bulgakov's ideal thus lacks the particular concentration of the entirety of divine-human powers in the phenomenon of prophecy and theurgic creativity, with their indivisibility of active and passive components, that we find in Soloviev's work.

18 N. Berdiaev, 'Problema Vostoka i zapada v religioznom soznanii Vl. Solov'eva,' in Kniga o Vladimire Solov'eve, pp. 355-73 (pp. 365, 366). 
but rather the judgment it makes on his theanthropic project. The kind of erotic mysticism pursued by Soloviev, argues Berdiaev, is by its very nature incapable of achieving that union between humanity and the divine on which his entire philosophy is premised. ${ }^{19}$ The place of love, and most especially erotic love, in the theanthropic economy thus needs to be examined in detail to ascertain its precise character.

Soloviev's approach is notable not merely for its attempt, in his work The Meaning of Love (1892-94), to articulate a Christian philosophy of love that included its erotic and sexual aspects. It is so, primarily, for the extent that it actually diverges from the Christian model of love in favour of a modified Platonism centred on an eschatological interpretation of eros. Indeed, Soloviev does not even try to integrate eros into the broader landscape of agapeic love, and though in the early work there are nods to the need to purge love of its dæmonic energy, in the late work on eschatological and soteriological themes eros appears to act with autonomy. For Soloviev, the erotic was the highest incarnation of both human and divine love or, more exactly, of the divine-human love realized in Christ and, in the new era of the Holy Spirit, harnessed by a conscious humanity. His conception of love is thus almost wholly subsumed by its erotic aspect, with a role accorded to an agapeic residue only in its lower, less perfect manifestations.

Related to this, Soloviev's treatment of love is remarkable for its overwhelming emphasis on materiality. There may be times when Soloviev's discourse is inexact and contradictory, but his use of the phrase 'resurrection of the flesh' as opposed to 'resurrection of the body' to describe eschatological consummation is certainly not accidental. 'Only flesh is illumined and spiritualized; flesh is the necessary object of love,' he wrote in The Meaning of Love. ${ }^{20}$ The only power that was capable of winning victory over death was a love that had as its object

19 Ruth Coates largely follows Berdiaev in assigning Soloviev, again with negative ramifications, to the Catholic mystical tradition. See Coates, 'Mystical Union,' pp. 14552. Adrian Pabst argues that the 'natural desire of all human and cosmic reality to surpass itself in the direction of the absolute,' far from being evidence of the object's location outside the desiring subject, is a 'sign that the absolute is always already related to the universe.' Pabst, 'Wisdom and the Art of Politics,' p. 126. $\mathrm{S}^{1}$, II, p. 520. 
that which was itself subject to death: the decaying, disintegrating flesh of the concrete human being. A love that directed itself at material phenomena in their ideal rather than actual materiality - that is, at the reality expressed by terms such as 'body,' which already contains a certain organization of spiritual forces over matter - might provide, in Soloviev's view, an ideal flight from death's fiat, but could never root it out at its core. ${ }^{21}$

In all Soloviev's writing on the nature and vocation of love, the importance of both the individual biography of Plato and his works, particularly the dialogues Symposium and Phaedrus, is impossible to overstate. His treatment of eros in The Life Drama of Plato, and the introduction to his translation of the Platonic dialogues, are thus key to an understanding of his philosophy of love and eschatology. He was drawn above all to the peculiar fact that, of all the many forms of love that were known to ancient Greece, Plato chooses the term eros for two of its seemingly most radically divergent manifestations.

Greek is not lacking in words for love, and if such a master of thought and word as Plato, philosophizing on the highest manifestation of human life, uses an expression that relates to lower, animal passion, then it is clear that the whole contradiction in the direction of these two psychical movements - elemental-animal and spiritual-human - does not invalidate the real commonality of their foundation, immediate object, and material. Love, as erotic pathos - in its highest or lowest manifestation - is not at all like love for God, for humankind, for parents or homeland, for brothers or friends - it is essentially love for corporeality, and the only question is for what purpose? What is love really striving for in regard to corporeality: is it so that the same elemental facts of emergence and disappearance can be repeated without end, that same Hadean victory of chaos, death and decay? Or does it strive to introduce the corporeal into real life in beauty, immortality and sempiternity?22

21 Soloviev's unenthusiastic description of agape as an 'ideal principle of spiritual and social union' in his encyclopaedia entry on 'Love' is illustrative of the general conclusion observed throughout his work: anything that is merely ideal, that is, which does not exert influence over the real, the material, is in essence powerless and unworthy of endorsement or praise. SS, x, p. 237.

$\mathrm{S}^{1}$, II, pp. 614-15. 
The way in which Soloviev poses the question leaves one in no doubt that the proper response can only be the latter. All-encompassing love, love that carried out its mission to the end, could not reconcile itself with the inevitability of death; 'actually loving someone, it is impossible to reconcile oneself with the assurance of their destruction. ${ }^{23}$ Erotic love, as 'love for corporeality,' is the only love that can result in such radical realization. ${ }^{24}$ Yet it holds within its essential nature the possibility of two radically divergent outcomes - death and immortality - and 'the contradiction between the two erotes is merely the contradiction between the moral and immoral relation to [corporeal] life and the corresponding contradiction between the goals and results of its activity in this life.'25 In this way, the entire antinomic thrust of Soloviev's thought on spirit and matter is subsumed in eros, understood as both the source of their disunity and the potential source for their reunification. In the eros of humanity in its animal aspect, matter is uncoupled from spirit; in eros as spiritually ennobled, or as a moral rather than elemental power, it is spiritualized. If we cast an eye back to Soloviev's early metaphysics, we find that the desire for being-corporeality that he posited as the source of the Fall in the materia prima (Satan) turns out to be that same desire which, in its spiritualized form, restores the creation to wholeness and brings it to fulfilment. And it is that same 'flesh,' as the principle of sin, that Christ welcomes into his being (in both his eternal and historical kenoses) and then makes the foundation for the body of God. ${ }^{26}$

'The mediating energy of love,' writes Kornblatt, 'continually reenacts the Incarnation. Each act of erotic pathos is the incarnation of heavenly spirit into matter, creating, or "giving birth" to a new whole.' Kornbatt, 'Transifguration of Plato,' p. 44.

The parallels here between Soloviev and recent Catholic theology on this point are more than striking. See, especially, P. Riches, 'Deification as Metaphysics: Christology, Desire and Filial Prayer,' in P. M. Candler Jr and C. Cunningham (eds), Belief and Metaphysics, Nottingham, 2007, pp. 345-73. Riches, echoing Jean Daniélou's statement that Christ 'recapitulates' the sin of Adam 'on a higher plane,' writes: 'In the recapitulation of the Adamic-story, the reproduction of the false-sequela [sequela, here, means something like 'path' - OS] of death, becomes the Sequela of resurrection into deification by grace. The divinity Adam sought to take by force and by a misguided logic is, in Christ, revealed to be what God eternally wills the human to receive as gift' (p. 348). The distinction between Soloviev and theologians such as Henri de Lubac, whom Riches 
Yet this ennobling of erotic love does not for Soloviev equate with its purification in agape. Rather, what we find in his work is not the instrumentalization of eros but its intensification, the realization of its essential nature, as such given fraudulently in the elemental thirst for corporeality. If it is to step into its true vocation, there is required of it a dual movement: firstly, the turning away from the purely corporeal and carnal to God as the source and rule of its being; and secondly, the turning back to the corporeal as the salvific object of divine love. If the ascending love of the human subject to God is erotic, the love of God uses this same human eros in its descent, only now working from its own centre through the medium of divinized humanity. It takes the moment of selfgiving given in the winged movement of reverential love, and transforms it into another form of self-affirmation: still a desire to possess, but to possess absolutely, integrally and eternally. Eros for Soloviev is thus the environment for a multitude of movements and agencies; it is 'the transition, the means, and the bond between the two worlds: it combines within itself both ideal and sensual nature. ${ }^{27}$ It is that liminal creature whose duty it is to 'build a bridge between heaven and earth': 28 it is the first impulse to reach for heaven, the material of which the bridge is constructed, and the final bond itself. Most perplexingly, it is in eros too that the underlying impulse of Soloviev's philosophy - the kenotic giving away to the other, in Christian tradition associated above all with the agapeic function of love - is realized. The height of self-assertion coincides with the height of self-renunciation. ${ }^{29}$

The complexity of these movements consists in the fact that they are but one; 'true love is indivisibly amor ascendens and amor descendens,

focuses on, lies once more in the former's refusal to associate such desire with will, which for de Lubac was 'the fundamental depth of substance of the human human person, a depth in which desire and reason are united' (p. 349).

27 SS, XII, p. 391.

$28 \mathrm{~S}^{1}$, II, p. 611.

29 Michael Meerson has noted the paradox involved in such movement. 'For Solovyov', he writes, 'love is the self-negation of the subject, the assertion of the other, but through which he realizes his own supreme self-assertion, since true self-assertion is achieved only through self-negation.' M.A. Meerson, The Trinity of Love in Modern Russian Theology: The Love Paradigm and the Retrieval of Western Medieval Love Mysticism in Modern Russian Trinitarian Thought (from Solovyov to Bulgakov), Quincy, IL, 1988, p. 31. 
or those two Aphrodites which Plato did well to distinguish, but poorly to separate.' ${ }^{30}$ Further, this unitary yet dual movement of the subject toward the other coincides with its goal: the ultimate destination of what Soloviev calls the 'erotic task' 31 is nothing other than eros itself, a dwelling in love that is the consciousness of itself in its own efficacy. It is to this identity of the various components of love, as well as their realization in an eschatological framework, that Soloviev gives the term 'erotic pathos' or the 'pathos of love.'

Although not abundantly present in the philosopher's discourse, the concept of pathos is surely the most crucial modification Soloviev brings to the Platonic theory of love, and has far-reaching consequences for his thought on human activity in the world. Although harking back to the division between pathos and ethos in Hellenistic thought, ${ }^{32}$ it picks up elements of Hegel's treatment of pathos in his Aesthetics, and was certainly influenced by Belinskii's further development of the term. ${ }^{33}$ The particular combination of pathos and love, however, seems to have emerged as strongly from the contingencies of the philosopher's

$S^{1}$, II, p. 534. The idea that eros is an ontic unity rather than a duality, which manifests itself as a unitary agency operating from two directions, is developed by Proclus and Pseudo-Dionysius, for whom, as Nygren explains, Eros is no longer merely an ascending love, but also and primarily a love that descends.' There is thus a 'unitary force of Eros permeating the whole universe and holding all things together.' Nygren, Agape and Eros, pp. 570, 578; A. H. Armstrong, 'Platonic Eros and Christian Agape,' Downside Review, 1964, 79, 105-21 (pp. 115-17). In his encyclopaedia entry on Proclus, Soloviev signalled him out as unique among the Neoplatonists in that he did not follow them in regarding matter as 'an extreme weakening of divine emanation, something defective or nonexistent, [but] derived it from the intelligible principle of limitlessness.' SS, x, p. 486. John Rist suggests that Eros exhibited a distinctly agapeic function even earlier: 'in the tradition of Platonism from the time of Plato himself Eros is seen not only as an appetitive, self-centred power, but as expansive and generous.' J. Rist, 'A Note on Eros and Agape in Pseudo-Dionysius,' Vigiliae Christianae, 20, 1966, 4, pp. 235-43 (p. 235). $S^{1}$, II, p. 614. 'The principle of evil, i.e. exclusive self-affirmation, which had plunged everything that exists into primordial chaos,' wrote Soloviev in Lectures, 'now steps forward once again in a new form as the conscious, free activity of the individual human $[\ldots]$ Without the power of the self-affirming personality, without the power of egoism the very good in humanity is powerless and cold, only an abstract idea.' $S^{2}$, II, pp. 141-42, 150. 'The final goal is not the external limitation of evil, but its inner rebirth into good.' Ibid., p. 530.

32 See Chapter III, note 134.

33 See G. W. F. Hegel, Aesthetics: Lectures on Fine Art, 2 vols, Oxford, 1998, I, pp. 232-35. 
biographical path, as well as his continuing reflection on the lessons to be taken from the lives of Plato and Pushkin, as it did from any purely intellectual influence.

In Justification of the Good, Soloviev writes that the 'pathos of love directs [humanity] onto the right path and the highest goal for that positive and abundant power that is contained within this pathos itself.' ${ }^{34}$ In other words, such pathos not only leads its subject to a consciousness of the task but also gives her the necessary tools - itself - in order to realize it. Accordingly, if we associate love with feeling, as Soloviev does, pathos can be understood as a creative feeling whose motives are not blind to itself, a feeling not led by an elemental lust for the other but by a conscious desire for the other in God (or a desire for the other to be in God). In some of the last words he wrote, Soloviev pointed to the uniqueness of the pathos of love as spiritual-material event:

The life of the soul is not exhausted by the interplay between idealtheoretical strivings, raising it into the intelligible realm of pure forms, and material-practical stimuli, sinking it into the dark stream of deceptive 'flux' (byvanie). There is in the human being a fact and a factor, which cannot be reduced to the material nor the spiritual principle alone, but contains both indivisibly. Anyone who has experienced the quintessentially human pathos of personal love knows that one cannot attribute it in essence either to spiritual or to carnal needs, for both of these can be satisfied without this love, and that here we have to do with something particular, independent and intermediate, relating exactly neither to the one nor to the other aspect of our nature, but to its wholeness, or fullness. ${ }^{35}$

The pathos of love as state of consciousness has its own particular environment, reducible neither to the spiritual nor to the material, but containing both in their interaction, unity, or wholeness. Its strength as eschatological principle lies not in the universalization of its mandate, as if the object of human love could be a multitude of things simultaneously, but in its intensification. ${ }^{36}$ 'The lover really sees

34

35

36

$S^{1}$, I, p. 230.

SS, XII, p. 390.

This represents a change from Soloviev's views on love in Critique, where he posits the need for the intensity of love to become correlated with the universality of its object. PSS, III, p. 43. 
and visually perceives things which others do not,' ${ }^{37}$ writes Soloviev; erotic love is therefore the 'most concentrated, most concrete, and thus the deepest and strongest: it is the true foundation and the general type of any other love.' ${ }^{38}$ And it is this enhanced, concentrated vision, characteristic of individual love, that he posits as the condition for eschatological consummation. In adopting such a position, however, he is faced with the problem of explaining how this emphatically individual phenomenon relates not only to individual fulfilment but to that of the universe at a cosmic level.

If the meaning of the world is the 'inner unity of each with all,' writes Soloviev, then 'in the form of a living, personal power this unity is love. ${ }^{39}$ In other words, love is that determination at the core of the subject's being which positions it positively vis-à-vis the other, or unites its subject with the other. But this unity differs according to its kind. 'The quality of being-in-love differs from other types of individual human love - parental and childish, brotherly etc. - in particular,' writes Soloviev, "by its indivisible unity of the spiritual and physical aspects. ${ }^{40}$ By this he means, firstly, that the object of erotic love is loved as much in its physical aspect as its spiritual aspect: the lover is 'attached to both with an identical intensity of feeling. ${ }^{41}$ Secondly, and most interestingly, he means that there is as much of the spiritual in the experience of erotic love as there is of the physical. To put it another way, in erotic pathos it is both the spirit ('God') and matter ('flesh') that are loving in equal measure; and, conversely, it is both spirit and matter that are being loved. Unlike the descending love of the parent toward child, which gives more than it receives, and the love of the child toward parent, which receives more than it gives, in erotic love the giving and the receiving are, as Soloviev puts it, 'balanced' (uravnovesheno). Thus, alongside the traditional conceptual pair amor ascendens and amor descendens, the philosopher introduces a third kind of love, representing their synthetic resolution: amor aequalis

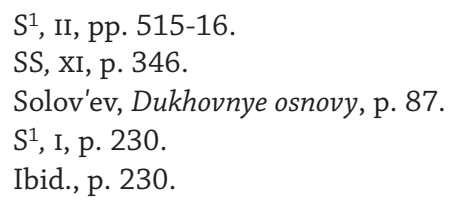


(equal love). ${ }^{42}$ The significance of amor aequalis, which we submit as a synonym for the pathos of love, is that in it spirit and matter are united in human feeling. ${ }^{43}$ Seen from this perspective, the pathos of love becomes the realization of the meaning of human nature as mediator between the spiritual and material realms, or the space of their concrete unity. ${ }^{44}$

The most difficult question of all in regard to Soloviev's philosophy of love is how to characterize the ideal interaction between spirit and matter in erotic pathos taken in its eschatological aspect, and how this differs from the intensity of the erotic relationship as found in everyday life. The philosopher is insistent that his ideal does not involve a return to a purely ideal model of love outside sensuality.

If eros is the striving of that which exists in material form toward ideal being, then this is not yet a striving to return to ideal being. In this latter everything is eternal and does not require fulfilment since it cannot lose

SS, x, p. 236. Amor aequalis appears to be a Solovievian innovation, although the phrase was used in connection with Emperor Valentinian I. See The Jesuit Series, ed. P. M. Daly and G. R. Dimler, 5 vols, Toronto, 2002, III, p. 94. It is possible that it had roots in early Gnosticism.

43 In this respect, Soloviev's erotic pathos differs from pathos in the Hegelian sense. For Hegel, pathos was 'an inherently justified power over the heart, an essential content of rationality and freedom of will [...] the essential rational content which is present in man's self and fills and penetrates his whole heart' or, as Geoffrey Mure has put it, 'a passionate absorption in fulfilling a one-sided ethical purpose.' Hegel, Aesthetics, p. 232; G. R. G. Mure, The Philosophy of Hegel, London, 1965, p. 192. Soloviev does not deny that pathos includes rationality, but argues that the heart is penetrated not by reason but by love. Further, this 'equal love' is the opposite of one-sided, subjective activity, representing instead the unity of opposing terms, the final break out of subjectivity.

44 Belinskii understood pathos precisely in terms of unity, both in the process of creation and as eternally realized. Pathos, he wrote in praise of Gogol"s Dead Souls, was what allowed the artist 'to let the phenomena of the external world pass through his living soul, thus breathing a living soul into them.' In an article on Lermontov, he spoke of that 'divine pathos which makes one's heart beat in unison with the cosmos [...] that divine pathos through which the terrestrial shines divine, the divine merges with the terrestrial, and all Nature appears in the brilliance of her wedding finery, an unriddled hieroglyph of the Spirit, now reconciled to her.' Cited in V. Terras, Belinskij and Russian Literary Criticism: the Heritage of Organic Aesthetics, Madison, WI, 1974, pp. 40, 84. Terras argues that Belinskii's concept of pathos is identical with Hegel's, 'though it somewhat overemphasizes the emotional side of artistic creation' (p. 137). This weight on the emotional aspect seems to us to be more important than Terras allows. 
anything. The striving is not to find a way back to a form of ideal being but to realize the eternal form, the ideal essence in that material process from which this striving derives. ${ }^{45}$

Soloviev's great reproach to Plato was that the Greek philosopher had 'arrived with his mind and feeling at an understanding of the true task of life, both universal and personal,' but had turned out to be the 'greatest of the misfortunates' since 'he had not attached himself with his whole soul to the true task revealed to his mind,' preferring the contemplation of pure ideas to the exhortations of Eros. The extent to which Soloviev's ideal incorporated the physical aspect of human love can be seen from a sermon belonging to a Masonic priest in Aleksei Pisemskii's 1880 novel Masons, written by the philosopher at the novelist's request:

Today, after the new Adam restored the spiritual union with the new Eve, that is, the Church, each separate person, becoming the image of this heavenly Adam, should even in his natural union with his wife have as its foundation the pure spiritual love which is in the union of Christ with the Church; then even in carnal togetherness not only will the heavenly light be retained, but the flesh itself will also be spiritualized, as the body of Christ was spiritualized. In this way we can channel and, through this, realize the union of God with nature that was restored in Christ in and through corporeal interaction itself, if only external union will be for us not a goal and not the first motive but only the extreme expression and final consummation of that inner spiritual unity of which the Lord himself said: 'that which God has joined, let no man separate.'46

Everything depended on this last condition, which guaranteed the purity of external, fleshly union as the 'final consummation' of the inner spiritual unity given in the pathos of love. ${ }^{47}$ Soloviev's peculiar attitude toward the 'physiological aspect of the matter,' 48 as he squeamishly refers to it in The Meaning of Love, did not derive from any existential vacillation between the justification and repudiation

Solov'ev, 'Lektsii po istorii filosofii,' p. 131.

Solov'ev, Pis'ma i prilozhenie, Brussels, 1970, IV, pp. 308-308.

Another important constituent to Soloviev's theory of love in its eschatological aspect is his development of Plato's myth of the androgyne, which was later taken up by the Kabbala, on which see J. D. Kornblatt, 'Solov'ev's Androgynous Sophia and the Jewish Kabbalah,' Slavic Review, 50, 1991, 3, pp. 487-496.

$\mathrm{S}^{1}$, II, p. 511. 
of sexual union (as, for example, in the life and work of Leo Tolstoy), but rather from the very nature of his philosophical eros, which was both summum malum - the perpetuator of 'bad infinity,' the inflamer of carnal lust - and, at least potentially, summum bonum - the last fruit of spiritual-material consummation. It was this fateful proximity of good and evil that was to become embodied in his Antichrist, and it was, as we have argued, in the character of Antichristic love that he becomes known as such. There is thus an intrinsic contiguity between Soloviev's development of his philosophy of love and the apocalypticism of the last years. To become located in the pathos of love was to face the irreducible tension of a battle waged at a single pole: the pathos of love was the pathos of the end.

This concentration to an individual point of intensity, felt and intuited as pathos rather than attained by the mind, is the major change between Soloviev's middle and late periods. As is evident from an important letter of 1897 titled 'Two Streams,' the philosopher had indeed come to believe that the energies of his best years had been 'wasted on empty, or fantastical goals. 49 Yet by this he did not mean theocracy per se but rather his previously held notion that any actual unity must be preceded by a realized social coherence on a universal level, a unified church or a theocratic society. This belief is shattered in the dénouement to Short Story of the Antichrist where a kind of radical disunity amongst temporal and spiritual powers, as well as amongst Christians themselves, is the backdrop to the apocalyptic realization of unity depicted in its last pages. By positing the locus of concrete unity in the pathos of erotic love, Soloviev reined in the circumference of the eschaton from the limits of the societal whole to a focus in the life of the individual. But this move away from expansive toward intensive realization, as he goes on to note in the 1897 letter, leads to great difficulties - the formulation of a 'paradoxical task,' the actualization of world meaning not only for the spirit, as it was in Hegel, but for a necessarily expansive material world. 'How is it,' Soloviev asks,

49 SS, x, p. 47. The letter is the fifteenth in a series of twenty-two 'Sunday Letters,' written on different social and religious themes in 1897-98, and published as an appendix to Three Conversations. 
'that by means of small powers an infinite, moral magnitude can be realized?'50 He goes some way toward giving the answer by postulating the condition for the spiritualization, and resulting expansion, of the erotic impulse in an act on the part of the individual - described elsewhere as 'a spiritual-physical, theanthropic feat' 51 - which he characterizes in the following terms:

That inner act, by which awakened passion is restrained from external expression, and the power of the soul, instead of dissipating itself in exteriority, is concentrated, absorbed within. Can this act, or this energy, really go nowhere? And, given that it has not turned into anything external, where then can it go except to the strengthening of the psychical being itself, food for its immortality [...] The external stream, which tries to take away our soul, should be counteracted not by stoic indifference but by a new feeling, answering good for evil and giving birth inside the soul to another, independent stream of movements and actions, ever more expanding and strengthening our being (sushchestvo). 52

This may sound very much like a form of repression, but Soloviev is clear in The Meaning of Love that this act, identical with the energy of the pathos of love, is not only a subjective feeling - a turning inward - but also the beginning of an outward movement, the birth of a new, 'independent stream' of movements, ${ }^{53}$ or 'real spiritual-

53 Here Soloviev seems to part ways with Plato's theory of love, which Gregory Vlastos has described as 'fully sensual in its resonance, but denying itself consummation, transmuting physical excitement into imaginative and intellectual energy.' G. Vlastos, Platonic Studies, Princeton, 1973, pp. 22-23. In Soloviev, the energy produced from such movement is sensual both in resonance and effect. Aleksei Losev, however, saw a fundamental synchronization of views between Soloviev and the Plato of Symposium on the question of outer, physical consummation. 'Plato wants that kind of transfiguration of the world in which flesh would be pure, the flesh precisely of the spirit, and not an evil principle.' A. Losev, 'Eros u Platona,' in Bytie, imia, kosmos, Moscow, 1993, pp. 32-60 (p. 55). Olga Matich suggests that 'what Solov'ev prohibits is coitus, without, however, pathologizing sex. This is the paradoxical meaning of his erotic utopia and one of the fundamental causes of its unrealizability.' Olga Matich, Erotic Utopia: The Decadent Imagination in Russia's Fin de Siècle, Madison, WI, 2004, p. 71. 
corporeal currents, 54 as he calls them, where the philosopher returns to the biblical discourse around the image and likeness of God, this time linking the practice of love with the distance between the two:

Apart from the material and empirical content of his life, each human being contains in itself the image of God, i.e. a particular form of absolute content. This image of God is known theoretically and abstractly to us in reason and through reason, but in love it is known concretely and vitally. And if this revelation of an ideal being (sushchestvo), ordinarily closed to material phenomena, is not limited to inner feeling alone but sometimes becomes sensible in the sphere of external feelings, then how much more significance should we accord love as the beginning of the visible restoration of the image of God in the material world, the beginning of the incarnation of true, ideal humanity (chelovechnost'). The power of love, transitioning into light, transforming and spiritualizing the form of external phenomena, reveals to us its objective might. ${ }^{55}$

This was as far as Soloviev reached in his treatment of the subjective conditions for the spiritualization of matter. From the movement of love issuing from a divinized humanity, our attention must now turn to the outward realization of this love in an objective, spiritualized materiality, the eschatological idea as such — beauty.

\section{BEAUTY}

Many commentators have recognized that the core of Soloviev's aesthetics coincides with his eschatology. It provides the 'answer to the question that had long troubled the philosopher about the fate and meaning of matter [...] Beauty is the initiation of material being into the moral order through its illumination and spiritualization.'56 As Irene Masing-Delic has noted, 'aesthetics is key to Soloviev's salvation program. Beauty corrects the fatal structural and textural

56 V.Asmus, and others, 'Solov'ev, Vladimir Sergeevich,' in Filosofskaia entsiklopediia, ed. F. B. Konstantinov, 5 vols, Moscow, 1960-70, v, pp. 51-56 (p. 54). 
flaw that Sophia's fall into materiality entailed.'57 Less developed, however, has been the connection between Soloviev's philosophy of love and his aesthetics in the eschatological context. In his 1889 essay 'Beauty in Nature,' the philosopher writes about love and beauty as two sides of the same 'world meaning,' which together constitute a 'living balance':

The true meaning of the universe - the individual incarnation of the life of the world, the living balance between the singular and the general, or the presence of all in one-this meaning, finding itself the most concentrated expression for inner feeling in sexual love, is the very same thing that for contemplation appears as the beauty of nature. In the feeling of love, annulling my egoism, I feel inside myself in the most intensive way the same Divine power that manifests itself outside me extensively in the creation of natural beauty, annulling material chaos, which is at its foundation that same egoism which works in me. The inner identity of these two manifestations of world meaning is clearly revealed to us in those poems where the poetic image of nature merges with the motif of love. ${ }^{58}$

In many ways this passage represents yet another formulation of the central idea of the Philosophy of All-Unity - the ontic correspondence between the individual and the universal, an idea found under other guises from the very earliest period of Soloviev's career. In his Critique, for example, he had written that 'to fully perceive one object, one being, i.e. to perceive it as it truly is, means to perceive everything; for in its true definition any object is connected with all in unity, or is a unity of itself and all.'59 The legal philosopher and historian Boris Chicherin responded to the work, and in particular this idea, with a wideranging attack on Soloviev's argument in an article titled 'Mysticism in Science' (1880). His central accusation centred around the claim that Soloviev's so-called 'unity of substance excludes the independence of separate creatures, reducing them to the level of mere phenomena.'60

FI, p. 418.

PSS, III, p. 306.

Cited in Ibid., p. 465. 
Uncharacteristically, Soloviev did not respond to the criticism, but it seems likely that it spurred him on to look for a more concrete link between individual and universal than the mere logical postulation of the 'all-one existent.' Such a link he found at the empirical level in the form of the pathos of love and the phenomenon of beauty, in which he intuited a 'living balance' between the one and the many. Returning to the above passage, we may note that this balance manifests itself in three ways: firstly, in the pathos of love as subjective feeling, or state of consciousness; secondly, in beauty as objective appearance, or the 'object of contemplation'; and thirdly, in the 'inner identity' of both. We have dealt with the balance of love in amor aequalis. Let us now deal briefly with the second point before moving on to the third.

In the same essay, Soloviev explains the peculiar beauty of the diamond in the following way:

The play of light, captured and modified by this body, perfectly covers its coarsely material appearance and, though the dark material of carbon is present here too, as it is in coal, it is only as the bearer (nositel'nitsa) of another, luminous principle which, in this play of lights, reveals its own content. ${ }^{61}$

The beauty that arises from this 'play of light' is not only, in Soloviev's view, the production of the light, or 'luminous principle,' but just as strongly that of the material - carbon - in which this play takes place. 'Beauty, belonging neither to the material body of the diamond, nor to the ray of light refracted in it, is the product of both in their interaction.'62 Beauty, as such, is thus the objective counterpart of erotic pathos, in which the spiritual and material aspects mutually fulfil each other: matter provides the foundation on which spirit ('light') can realize itself in concrete form, while spirit provides the principle of illumination itself, through which matter is transfigured. ${ }^{63}$ Being

61 Ibid., p. 37.

62 Ibid., p. 37.

63 In concrete terms, the 'spiritualization of matter' is always presented by Soloviev as the 'illumination of matter.' Light is also the constant background of his mystical experience. Siiat' - to shine - is the active verb used repeatedly to herald the entry of Sophia into his poetic framework. She is described as the 'radiant one' (luchezarnaia), 
the activity of neither principle in its singular orientation toward its object, beauty becomes the space of true, prophetic freedom. ${ }^{64}$ Most importantly, we have here a freedom that does not come into being by means of a break-through into the world of the in-itself, i.e. through a separation from the appearance of things. Rather, beauty is a 'phenomenological realization.' It rests on the perception of the viewer which witnesses to the balance of its spiritual-material nature: 'visible beauty is the true, accomplished goal.'65

Alongside this exaltation of natural beauty, however, which reaches its highest pitch in Soloviev's Lake Saimaa poems, his philosophy evinces a continuous disappointment in beauty's inability to retain, or reproduce, itself in an undying progression, to transfigure the world at its core. 'The beauty of nature is really only a cover thrown on evil life, and not the transformation of this life.' ${ }^{66}$ Natural beauty is ephemeral; even the diamond fails to shine at night. Therefore, as we have seen, the 'aesthetic task' moves up a level to the human realm, where the artist contemplates the eternal ideas so that she may sow them in material form, and in which beauty reaches a new, conscious intensity. Even this, however, cannot satisfy Soloviev. 'In human life, artistic beauty is only a symbol of a better hope, a momentary rainbow on the dark backdrop of our chaotic existence.'67 Indeed, his reader gets a sense that the externalization of spiritual content in artistic form is for him a kind of evasion tactic, a substitution of the true task for its close, yet ultimately insufficient, approximation. There always remained in the visionary-poet Soloviev a conviction that the

and it is precisely in her luminosity that her 'activity' is manifested. See my 'Sophianic Task,' pp. 173-74. See, also Bulgakov, who writes that 'spiritual beauty is not only the outward adornment by beauty but also the illumination by beauty from within; it is a question of incarnate spirit, not soulless body.' Bulgakov, The Comforter, p. 204.

Caryl Emerson writes in this connection that for Soloviev beauty is not the realization of some abstract ideal form' but a 'quality brought about through a dynamic, open, but at all times necessarily contested relation between an embodied and an unembodied force.' C. Emerson, 'Solov'ev, the late Tolstoi, and the Early Bakhtin on the Problem of Shame and Love,' Slavic Review, 50, 3, 1991, pp. 663-71 (p. 666).

65 V. V. Bychkov, Russkaia teurgicheskaia estetika, Moscow, 2007, pp. 62-63.

66 FI, p. 76.

67 Ibid., p. 31. 
primacy of natural beauty as beheld in the eye of the aesthete is worth more than its reworking on canvas or verse. It was this conviction that had led him to place 'mistika' as the highest of all the arts in Philosophical Principles, ${ }^{68}$ and to describe his new art - 'theurgy' — as the transfiguration of natural reality itself.

In the context of aesthetics, the 'inner identity' of love and beauty did not only consist, in Soloviev's view, in the fact that what is revealed in the former intensively is the same thing that is revealed in the latter extensively. In artistic creation, the philosopher posits an interaction between the two principles so that the content of erotic pathos is in some respect constitutive of beauty: love, as subjective feeling, spills over into beauty. This 'spilling over' is the final realization of the vocation of Eros, who is 'love, as the striving to create in the beautiful, or love to give birth to the beautiful.' ${ }^{\prime}$ In other words, love is both an engendering of the beautiful and the act of creating in the beautiful. In this way, love and beauty find themselves in the same relation to one another as spirit and matter in the individual case of the beauty of the diamond: they are mutually conditioning, engendering - a unity of giving and receiving. Here Soloviev follows almost exactly Diotima's argument in Symposium, which proceeds from the threefold contention, acknowledged by Socrates, that 'we love only what is beautiful; in loving it we desire to possess it in perpetuity'; and that 'we desire to possess it because it is good, and expect that its possession would make us happy, ${ }^{70}$ to the conclusion, which baffles Socrates, that to serve this end requires 'birth in beauty.' Gregory Vlastos interprets these words as follows: 'beauty stirs us so deeply, Plato is saying, because we have the power to create and only the beauty we love can release that power.'71 Plato then proceeds to paint a picture of sexual love which, though it finds some resonance in Soloviev's work, ultimately left the latter with

PSS, II, p. 196.

Solov'ev, 'Lektsii po istorii filosofii,' p. 131. The idea is found in Symposium where, when Diotima is asked in what the activity of those who follow Eros consists, she answers: 'Love's function is giving birth in beauty both in body and in mind.' Plato, Symposium, p. 43.

Ibid., p. 41.

Vlastos, Platonic Studies, p. 21. 
the feeling that something had remained unsaid. Even worse, he not only sees inadequacy in the articulation of Plato's ideal but, in the years that follow the writing of the two great dialogues on love, its betrayal: 'the momentary ascent of Plato's thought to the idea of Eros as a bridge connecting the world of the truly-existent with that of material reality remained without repercussions. The philosopher pointed the way to this bridge in enigmatic expressions, but proved unable to step onto it himself, or lead others across. ${ }^{72}$

Despite this damning assessment, the 'fall' of Plato, seen in Soloviev's opinion in its most pitiful unravelling in the writing of the Laws at the end of his life, did not repel him from the Greek philosopher. If anything, it made him draw ever closer to the Platonic corpus, wishing to uncover its dynamism, its meaning, its tragedy, and its promise. ${ }^{73}$ The drama of Plato's life was not a matter of academic interest to Soloviev: it was the archetype, the meta-narrative, of the prophetic-philosophical path - that concrete historical example in which philosophy had discovered the wings to ascend to the prophetic heights yet, like Icarus, had come crashing down to Earth. Plato had 'approached conceptually the creative task of Eros, understood it as the task of life - "birth in beauty" - but did not define the ultimate content of that task, not to speak of its fulfilment.'74 Soloviev's aesthetics and philosophy of love should be seen not as an attempt to build an alternative model to that of Plato but rather to regain that height of erotic inspiration once attained

S1, II, p. 327.

73 The introduction to Soloviev's translation of the Platonic dialogues exhibits a fascination, bordering on obsession, with determining their exact chronology. An interpretation of the dialogues themselves could only rest, in his view, on a proper understanding of the evolution of the individual who gave them life. Sergei Trubetskoi talked about the 'remarkable congeniality' that drew the philosopher to Plato, while for Losev, 'only Vladimir Soloviev [managed] to find in his soul real contact with Plato's philosophy, and was the first to realize a purely intuitive, spontaneous and living approach to the philosopher.' Trubetskoi, 'Predislovie,' p. 497; Losev, 'Eros u Platona,' p. 37. Soloviev believed the peak of Plato's creativity - the writing of Symposium and Phaedrus - to have coincided with an 'erotic crisis.' S1, II, p. 608. This conclusion has ramifications not only for the way he wished his reader to interpret the 'fall' of Plato, but how we interpret the truly Platonic task that Soloviev sees himself as continuing. $S^{1}$, II, p. 619. 
by the latter, to elucidate the content of the task there attained, and to realize it. It was thus a quintessentially Platonic endeavour; indeed, it was to be more Platonic than Plato himself.

We find a fascinating link between Soloviev's late re-immersion in Plato and the apocalypticism of Short Story of the Antichrist in the words spoken to the Antichrist by the 'metallic and completely soulless' voice the reader takes to be that of the devil near the beginning of the story: 'As before my spirit gave birth to you in beauty, so now it gives birth to you in power.' It is at the sound of these words that the Antichrist's mouth opens and a 'sharp, icy stream entered into him, and filled his whole being. ${ }^{75}$ The phrase acts as a kind of magical initiation into falsehood, and the scene as a whole is analogous to the biblical depictions of prophetic calling, yet whose agent is here the enemy of God rather than God herself. What does it mean for the devil to give birth to the Antichrist in beauty, and then power? It is hard not to see in these words a resonance with Soloviev's reflections on the life-drama of Plato. Having ascended in love to the striving for birth in beauty, Plato had been pulled back, writes Soloviev, by two opposing tendencies: the conviction that 'ideal truth can only be reflected or imprinted on the surface of real being, and not incarnate in it essentially,' and that the 'spirit is only connected to this reality in a transitory and external way. ${ }^{76}$ In the commission of the Antichrist by his master in Short Story we find a kind of narrative expansion of the existential decision taken by Plato to renounce the higher task of Eros. The devil, as hypostatized self-love, gives birth to the Antichrist in beauty. It is not love itself that births beauty but its opposite: the creativity of beauty does not arise from an inner erotic pathos but is enforced on its object by the will of the begetter. The Antichrist is 'Christ turned-inside-out,' to recall Soloviev's definition, insofar as his beauty is worn on the outside; it does not arise from the love in which he dwells but instead superficially covers his external form as the ultimate semblance of good. This point is expertly brought out by Lithuanian philosopher Antanas Matseina, who writes that satanic beauty for Soloviev 'is that clothing in which the

75 Ibid., pp. 742-43.

76 Ibid., p. 321. 
devil arrays his supporters and their works so as to attract to himself members of Christ's Kingdom.'77

'Birth in power' is from this perspective the logical conclusion of such one-sided birth in beauty - beauty that arises not from the equal, divine-human love of amor aequalis but from the satanic will which finds in beauty not itself in rebirth but merely a means for power. It is the end point of that kind of beauty that stops at surface level, not resurrecting human nature from within but deceptively imposing itself on human form from without. Only the one whose image is set at the core of human inner being can give birth from within; the devil must work with externalities. It is also the end point of the drama of Plato's life in Soloviev's handling: the disintegration of beauty into power that characterizes the Republic and, most definitively, the Laws.

The theme of counterfeit beauty permeates the work of Soloviev's late period. While the philosopher found almost no attempt to describe in philosophical terms the actual transition of erotic pathos into birth in beauty in Plato, the tremendous value of the Hegelian dialectic for him consisted in its depiction of the inner dynamism of this process. Like Soloviev, Hegel, for whom the disclosure and self-discovery of inner consciousness in external form was the final realization of spirit, which in such recognition 'knows itself for the first time, ${ }^{78}$ wrote about the creative process in terms of the transition of an intensive pathos into an expansive externality.

Now such 'pathos' essentially demands representation and graphic amplification. And at that it must be a soul inherently rich which puts into its 'pathos' the wealth of its inner being and does not merely concentrate itself in itself and remain intensive, but expresses itself extensively and rises to a fully developed form [...] In order to be concrete in itself, as ideal art requires, the 'pathos' must come into representation as the

77 A. Matseina, Taina bezzakoniia, St Petersburg, 1999, p. 115. Soloviev makes a point of describing the 'beauty' and 'nobility' of the Antichrist. When he appears on stage as the president of the European United States, for example, Soloviev remarks on the 'brilliance of his superhuman young beauty and power.' S1, II, pp. 740, 745.

78 Consciousness 'must see how it has externalized itself in various objects, and in seeing this also cancelled the externalization. It must see all its objective forms as itself.' Hegel, Phenomenology of Spirit, p. 589. 
'pathos' of a rich and total spirit [...] Feeling must completely either disclose itself on its own account or shine clearly and thoroughly through the external material in which it has enshrined itself. ${ }^{79}$

While Hegel's remarks follow very closely the thrust of Soloviev's aesthetics in its continual thirst for the external expression of inner content, there are several substantial differences between the two. The most crucial is the complete lack of anything approximating Solovievian balance (ravnovesie) in Hegel's account. For Hegel, spirit (Geist) is located in an emphatically one-sided relation to material form, which itself derives from the one-sidedness of his pathos: spirit forces its way into matter through the sheer energy of its own self-negating dialectic. Michael Meerson comments that the universal and eternal idea is for Hegel 'embodied' in beauty whereas for Soloviev beauty is itself 'the interaction between spiritual and material elements. Through this interaction, the material element is elevated to the eternal status of the spiritual.' ${ }^{80}$ Soloviev writes:

In Hegelian aesthetics, beauty is an incarnation of the universal and eternal idea in individual and transitory phenomena. Yet this is how they remain - transitory, vanishing like disconnected waves in the flow of the material process, reflecting only for a minute the radiance of the eternal idea. But this is possible only in an indifferent relation between the spiritual principle and material principle. ${ }^{81}$

It is this indifference, in Soloviev's eyes, of relation between the spiritual and material that produces the superficiality of Hegelian beauty. ${ }^{82}$ The ideal glimmers in the object but is not brought to birth in it; the erotic pathos, in which spirit and matter are equalized in love, becomes the pathos of power - the idea dictates and, in its dominion, loses the path to its true freedom, for it is in slavery to the one who desires only himself.

Meerson, Trinity of Love, p. 35.

FI, p. 81.

82 The discussion here does not relate to natural or artistic beauty but to the perception, or consciousness, of that beauty, from which in any case it cannot be separated. 
In Hegelianism the philosophical subject comes closer than it ever has to its authentic and ultimate definition as the becoming reason of truth (razum istiny). But, having risen to this height, its head spins and it insanely imagines that the principle of its understanding (razumenie) of the truth is the inception of the truth itself, and that the truth's growth and development is its own growth and development. ${ }^{83}$

This tragic substitution by the subject of itself in place of the being in which it is involved ('pathos') 84 is for Soloviev the downfall of Hegel and his system. He lacked that 'intent or that act of will in its giving itself over to its object that is the real principle of movement,' 85 imagining his own self to be the ultimate creator of that space in which alone his selfhood could find its ultimate realization. Soloviev concludes his evaluation of Hegel in Theoretical Philosophy in biblical tones, writing that 'amongst the philosophers who have approached the truth, there is none greater than Hegel, yet even the least amongst the philosophers issuing from the truth itself is greater than he.' ${ }^{86}$

Perhaps the most remarkable treatment of superficial beauty as the renunciation of the pathos of love is found in Soloviev's 1899 article on Mikhail Lermontov. While recognizing that love motifs predominate in Lermontov's verse, Soloviev writes that these 'only partly possess the personal self-feeling (samochuvstvie) of the poet, blunting the sharpness of his egoism, softening his cruelty, but not completely filling or covering his ego.' 87 The philosopher goes on to

$83 S^{1}$, I, p. 829. Razum istiny (reason of truth) is the key technical term of Soloviev's late theoretical philosophy which, however, he did not manage to develop sufficiently before his death.

84 The idea of participation as being-in-pathos resonates with the Platonic concept methexis, which Christopher Bigger describes as "the name of the "relation" which accounts for the togetherness of elements of diverse ontological type in the essential unity of a single instance. In this sense it is real relation, one constitutive of the nexus qua nexus which arises from it.' C. P. Bigger, Participation: A Platonic Inquiry (Baton Rouge: Louisiana State Press, 1968), p. 8. Soloviev was surely aware of the term although he does not mention it. Bulgakov, however, writes: "Methexis, the participation of matter in the idea is precisely Eros, the eros of "earth" to "heaven".' Bulgakov, Svet nevechernii, p. 211.

85 S1, I, p. 830.

86 Ibid., p. 829. Compare Matthew 11.11.

87 FI, p. 385. 
intuit the 'victory of egoism' over the 'misfortunate effort of love' in every corner of Lermontov's poetry.

One feels that real significance belongs here not to love, not what it makes of the poet, but what he makes of it, how he relates to it. When a huge glacier is lit by the sun, it is, they say, an entrancing sight. But this new beauty occurs not because the sun makes something new of the glacier (it cannot, after all, melt it) but from what the glacier, remaining unchangingly itself, makes of the sun's rays, reflecting and refracting them in various ways on its surface. Such is the peculiar charm (prelest') of Lermontov's love poetry: an optical charm, the charm of a mirage. ${ }^{88}$

Taken together, the glacier and the diamond can be understood as symbols of the identity of radical difference in the Solovievian conception of beauty. ${ }^{89}$ The glacier as the natural archetype of nontransfigurative beauty - a beauty that is but the concealment of the void - and the diamond as the natural archetype of its oppositea beauty that penetrates to the core of its material, the birthing forth of an interior love that cannot set limits to itself - these two are the ambiguous poles of Soloviev's theory, the dual horizon of his aesthetic landscape. ${ }^{90}$ It is in their light that we arrive at the final philosophical model against which Soloviev wished to differentiate his own.

Ibid., p. 386.

Although he does not speak of beauty, Desmond has written in a similar way of the 'radical equivocity' of the Antichrist, 'the fact that the "sameness" of Christ and antiChrist is absolute difference.' Desmond, 'God Beyond the Whole,' p. 191.

Despite Soloviev's rejection of Hegelian aesthetics, these two poles carry distinct echoes of Hegel's use of the terms Schein (semblance) and Erscheinung (appearance), both of which express the Essence (Wesen) of an object but in different respects. In much the same way that Soloviev uses light in his treatment of glacier, Hegel uses Schein to express an outward shining that appears to communicate Essence but which in actuality only masks or veils it. Erscheinung, to the contrary, 'forms a connected totality of the ways the Essence shows itself from within, a totality whose horizon is the world as the collection of all possible relationships between the Essence and other things.' See T. Ryba, 'Manifestation,' in W, Braun and R. T. McCutcheon (eds), Guide to the Study of Religion, London, 2006, pp. 168-189 (pp. 176-77). Soloviev, while preserving a similar distinction between counterfeit Schein and authentic Erscheinung focuses rather on the human-active component in the realization of each. In his artice 'The Freedom of Will and Causality,' he posits the source of these differing 
If Sergei Trubetskoi talked of the congeniality between the Russian philosopher and Plato, it is surely justifiable to discuss yet another correspondence, this time with a figure who lived at the same time as Soloviev, died just twenty-six days after him, and in many ways had just as immense an influence on Russian thought as Soloviev himself - Friedrich Nietzsche. Here it is no longer a matter of congeniality but of correspondence in inversion: in all major points, seeming proximity between the two thinkers is eclipsed by their essential, radical divergence. Soloviev understood perhaps more profoundly than any other thinker in late-nineteenth-century Europe the danger of the illusory beauty that found conscious and expansive articulation, and, as such, repudiation, in Nietzscheanism. In Birth of Tragedy, Nietzsche had summed up the purpose of beauty in the following terms:

If we could imagine dissonance become man - and what else is man? - this dissonance, to be able to live, would need a splendid illusion that would cover dissonance with a veil of beauty. This is the true artistic aim of Apollo in whose name we comprehend all those countless illusions of the beauty of mere appearance that at every moment make life worth living at all and prompt the desire to live on in order to experience the next moment. ${ }^{91}$

Beauty for Nietzsche is thus the falsification of the real, the illusion that allows the weaker human being to go on living through believing the coddling lie of what Sonia Sikka has called the 'metaphysicoreligious interpretation' of beauty, which Nietzsche seeks to expose. ${ }^{92}$ In this understanding, beauty 'saves' not because it is true but because it is entirely delusory: 'the salvific power of the beautiful dream-vision resides entirely in its fraudulent character, in the fact that is an idealized,

products in activities he calls 'mechanism' and 'creativity' respectively: 'creativity is the realization or incarnation of the idea in matter; mechanism is the relative realization of the idea by means of (posredstvom) matter.' See Solov'ev, 'Freedom of Will and Causality,' p. 183.

91 F. Nietzsche, The Birth of Tragedy, New York, 1967, p. 25.

92 S. Sikka, 'On the Truth of Beauty: Nietzsche, Heidegger, Keats,' Heythrop Journal, 39, 1998, 3, pp. 243-63 (pp. 245-48). 
and thus falsified, image of life. ${ }^{93}$ Nietzsche, then, in refusing to accept the beautiful illusion, is the first to rise to a level where, instead of the 'indication of connection in and through an ontological ground' that appears to be given in such illusions, surveys the new horizon and sees what is really true: the utter separation of the individual from the whole, and its irrevocable path to total destruction and decay. The myth of eternal beauty becomes the coward's way out of the total suffering of absolute transience.

In a number of articles of the 1890s Soloviev battled against what he saw as the devaluation of beauty - a 'pagan view of power and beauty,' as he characterized Nietzscheanism ${ }^{94}$ - in the hands of contemporary Russian poets. In his 1894 'The Buddhist Disposition in Poetry,' he rails against the beauty he finds in the now barely known poetry of Arsenii Golenishchev-Kutuzov (1848-1913), 'powerless to rebirth its admirer to new life, promising him flight and oblivion alone,' and whose results were writ large in his verse: 'having become disillusioned in external and interior beauty, the author, naturally, loses faith in his own poetic vocation.95 Two months before his own death, Soloviev wrote an obituary for Vasilii Preobrazhenskii (1864-1900), the first Russian writer to undertake a systematic exposition of Nietzsche's philosophy, and translator and popularizer of the latter's ideas in Russian society. Preobrazhenskii's 1892 article, 'Friedrich Nietzsche, Critique of the Morality of Altruism, ${ }^{96}$ may have provided Soloviev with his first introduction to the German existentialist. ${ }^{97}$ To say that Soloviev did not share Preobrazhenskii's positive interpretation of Nietzsche is to

$93 \quad$ Ibid., p. 245.

$94 \quad S^{2}$, II, p. 612.

$95 \quad$ FI, p. 457.

96 V.P. Preobrazhenskii, 'Fridrikh Nitsshe, kritika morali al'truizma,' Voprosy filosofii $i$ psikhologii, 1892, 15, pp. 115-60.

97 It is likely that Soloviev, who for many years took an active role in the running of the journal Voprosy filosofii i psikhologii, had a part in writing the editorial note published at the head of Preobrazhenskii's article, which seeks to undercut the latter's positive assessment of Nietzsche's philosophy by reminding the reader what a 'great and meaningful lesson is given us in the fate of this misfortunate proud man, who ended up in a mental asylum as a consequence of an idée fixe that he was the Creator of the world.' Ibid., p. 115. The same idea occurs in similarly immoderate wording in Soloviev's 1897 'Sunday Letter' 'Philology or Truth?.' See SS, x, p. 29. 
put it mildly. In his obituary, however, Soloviev lays out his critique of Nietzsche while withholding judgement from his Russian admirer: 'only the truly beautiful (istinno-prekrasnoe) is worthy of love, and the truly beautiful is first of all the truly good. I had reason to think that even this "aesthete" recognized that the ultimate benchmark for all judgement resided in the ethical. ${ }^{\text {'9 }}$

The, in essence, Platonic idea that beauty is the only true object of love in which the good, far from ceding its ground to the aesthetic, finds its ultimate realization ${ }^{99}$ lies at the heart of Soloviev's work, particularly of the late period. For him, good was 'justified' precisely in beauty, or, to recall his celebrated triadic formulation, 'through truth in beauty.' His refusal to acknowledge 'aesthetic separatism' (the separation of the principle of beauty from other fields, particularly ethics) ${ }^{100}$ was the very crux of his conflict with Nietzsche and the Russian Nietzscheans. Yet more interesting, however, is the question of where such divergent convictions had their source, that is, which intuitions or foundational principles created the energy for his particular worldview. Here we return, finally, to a discussion of Nietzschean 'dissonance,' a term which, like so much in Nietzsche, contains a certain amount of ambiguity.

For Nietzsche, dissonance was a sensation containing within itself a kind of 'tragic pleasure.' Since it seeks not to deny the suffering of the world, which Nietzsche equated with the denial of life, the conscious living-through of dissonance coincides with the 'highest state of affirmation of existence,' which does not exclude even the 'highest degree of pain.'101 On the basis of Birth of Tragedy, Daniel Came has argued that there are at least two possible interpretations of the principle in Nietzsche's thought: firstly, that it refers to something which is pleasurable in itself, as a 'pleasure in dissonance'; and secondly, that 'it is not intrinsically pleasurable' but instead 'causally linked to something which is,' since 'dissonance causes the resolution that

\footnotetext{
98 Ibid., IX, p. 430.

99 The Greek word kalos can be translated as either good or beautiful.

100 The term occurs in the 1894 'First Step Toward a Positive Aesthetics' in relation to the kind of art that separates itself from all other spheres, thinking itself self-sufficient and self-defining. FI, p. 91.

101 F. Nietzsche, Will to Power, New York, 1968, p. 453.
} 
follows to sound more agreeable. ${ }^{102}$ Nevertheless, Came had due cause to settle on the first interpretation since, as he argues, dissonance must be understood as the 'aesthetic significance of the problematic aspects of existence' which, in themselves, according to Nietzsche, can and should receive no resolution. ${ }^{103}$ Resolution in beauty is the illusion of resolution; the dissonance between the individual and the whole, between the hope for eternity and the reality of unending death and decay, is itself evidence of their absolute non-contiguity and noncorrespondence. Only she who lives out the 'tragic pleasure' had in the feeling of dissonance aligns herself with what is true, where truth coincides with the negation of all good and truth, and the attainment of a position 'beyond good and evil.'

Soloviev was not afraid of dissonance, and did not seek to deny it. Indeed, as we have argued, the great impulse for his work was the distance between the world 'as it is' and the world 'as it should be' according to our desires. ${ }^{104}$ Yet for him the feeling, or experience, of beauty was not the irrevocable evidence of primal and absolute dissonance but the concrete, realized unity of the spiritual and material principles, not as a kind of spiritual diktat, as in Hegel, but as their living interaction as birth in beauty. On the other hand, anyone who reads Soloviev's Short Story, or any number of works of the middle and late periods, will be convinced of the philosopher's belief in the existence of that illusory beauty of which Nietzsche speaks. The apocalyptic turn in Soloviev's late period gives the lie to the words spoken in that early manifesto letter to Katia Romanova ('I do not believe in the devil') ${ }^{105}$ when, like Ivan Karamazov, he could no longer deny the personal agency of evil in the world. But, in regarding such beauty as false, he at the same time

D. Came, 'Nietzsche's Attempt at a Self-Criticism: Art and Morality in The Birth of Tragedy,' in Nietzsche-Studien, ed. M. Montinari, Berlin, 1974, pp. 37-67 (p. 57).

Ibid., p. 57.

Soloviev's Spiritual Foundations of Life begins with an unflinching expression of existential dissonance: 'The two great desires - immortality and truth - are counterposed by two great facts - the inevitable dominion of death over all flesh and the invincible rulership of sin over all souls. We only desire to rise above the rest of nature; death equates us with the entire earthly creation, and sin makes us worse than it.' Solov'ev, Dukhovnye osnovy, p. 24.

Solov'ev, "Nepodvizhno," p. 173. 
acknowledged the existence of an authentic beauty of which the other was the counterfeit. While both beauties were for him equally 'true' from a phenomenal perspective - insofar as they were both experienced as such - the truly beautiful is so only by dint of its connection with the truly good. Ultimately, the place of discernment can only rest in the subjective feeling involved in the emergence of the beautiful or, more exactly, the pathos that informs the differing experiences. While, for Nietzsche, beauty is merely an imagined resolution of ontic dissonance, for Soloviev it is the result, the ultimate fruit of an equally primary, ontic consonance between the individual and universal, in which the former develops on the path outlined in the previous sections, from faith through reverence to the attainment of the pathos of love. The difference is, however, that while there is nothing that can ultimately prove or disprove the Nietzschean assertion of absolute dissonance, for Soloviev the consonance of the divine and the human in amor aequalis does not, or should not, remain merely an interior pathos but should rather spills over into the birth of immortality in material form. As he writes in the introduction to the third edition of his collected poems (1900):

The more perfect and intimate the revelation of true beauty which clothes the Godhead and by Her power frees us from suffering and death, the narrower is the boundary separating it from its false image, from that illusory, powerless beauty which merely continues the kingdom of suffering and death. ${ }^{106}$

The uniqueness of Soloviev's late approach to this problem consists not only in the overcoming of evil by the good in beauty but also in the proximity between its two poles: as he writes, the more intimate and complete the manifestation of the truly beautiful, the less clear the boundary between counterfeit and authentic beauty becomes. By this he means, as we have said, that the final conflict between good and evil, waged in beauty, is not one of opposites but of superficial identity. But there is also a sense in Soloviev that the illusory beauty, which Nietzsche so reviled, itself becomes the place of transition to authentic beauty, by

SS, XII, p. 4. 
dying to itself and rebirthing. This removal of the border between true and false beauty, which does not equate with their 'merging,' comes through most strikingly in Soloviev's 'Sunday Letter,' Christ is Risen!, where the philosopher begins by developing a distinctly Nietzschean argument on the dominion of death, which 'knows that the beauty of nature is only a colourful and bright veil thrown on a continuously decomposing corpse.' ${ }^{107}$ Beauty 'appears eternal to the external eye, from the side, to the observer accepting this new, momentary life for the continuation of what came before.' But 'if what is born today is not the same as that which died yesterday but something else, then what cause have we to speak of rebirth?'108

Soloviev, like Nietzsche, accepted that the eternity of beauty is but a seeming eternity, that what it announces to the human spirit and soul is a message at odds with its real efficacy. But he had no wish to embrace the illusion, or even to renounce it in the name of the universal suffering of dissonance: 'No! This seeming life is only a symbol and the beginnings of true life; the organization of visible nature is not the decisive victory of the living spirit over death, but only its preparation for real actions.' ${ }^{109}$ This 'no' would be interpreted by Nietzsche as the cowardly return to the comfortable illusion, yet it is clear that for Soloviev such an act was far from comfortable. At the end of his life, amidst his growing fears in the presentness of the end, a side of his Christology which, while not ignored, had hitherto been, so to speak, subsumed in the power revealed in the Resurrection, comes to the fore. What he had once described as 'the inner theosis through the experience of the cross'110 is re-emphasized, and the moral power revealed in the cross moved to central place. As Soloviev writes in the same letter:

If physical power is inevitably conquered by death, the power of the mind is not enough to conquer death: only the limitlessness of moral power gives life its absolute fullness, excludes any dualism and, consequently, does not allow the definitive fall of a living being into two separate parts:

\footnotetext{
107 Ibid., X, p. 34.

108 Ibid., p. 34.

109 Ibid., p. 35

110 S $^{2}$, II, p. 228.
} 
fleshless spirit and decomposing matter. The crucified Son of Man and Son of God, having felt himself abandoned by both people and God and yet praying for his enemies, clearly had no limits to his spiritual power, and no part of his being could become death's trophy. ${ }^{111}$

Christ's ability to continue to love, even in a situation in which the very heights of dissonance between the individual, his environment, and the absolute itself, are reached and felt as such, ${ }^{112}$ is here presented as the condition for his Resurrection, and the connection made between the true eternity of beauty and such love. Thus, alongside the importance of reverence, which had possessed him during his blissful solitude at the side of Lake Saimaa, there appears another feeling in late Soloviev: the descent into the very pit of Nietzschean abandonment, a feeling through of death as the destroyer of all relation yet, at the same time, the breaking through of such radical abandonment by the limitless moral power of love. The pathos of love, the pathos of the end, and the pathos of the cross become different ways of expressing the same thing. There is a dissonance that only love can overcome, and there is a love that can only fully overcome by descending into dissonance. That Soloviev, who for so long had hoped for the gradual realization in the historical order of that consonance between spirit and matter announced to him in his sophianic visions, should late in life embrace the tragic dissonance of the pathos of the end, yet at the same time remain convinced of the saving power of beauty brought to birth by love, was perhaps not the only possible dénouement to his life's drama, but it is surely a fitting one.

111 SS, x, p. 36.

112 We recall Soloviev's definition of the prophet as one 'in whom the contradiction with the social environment that surrounds him reaches absolute incommensurability.' See p. 153. 